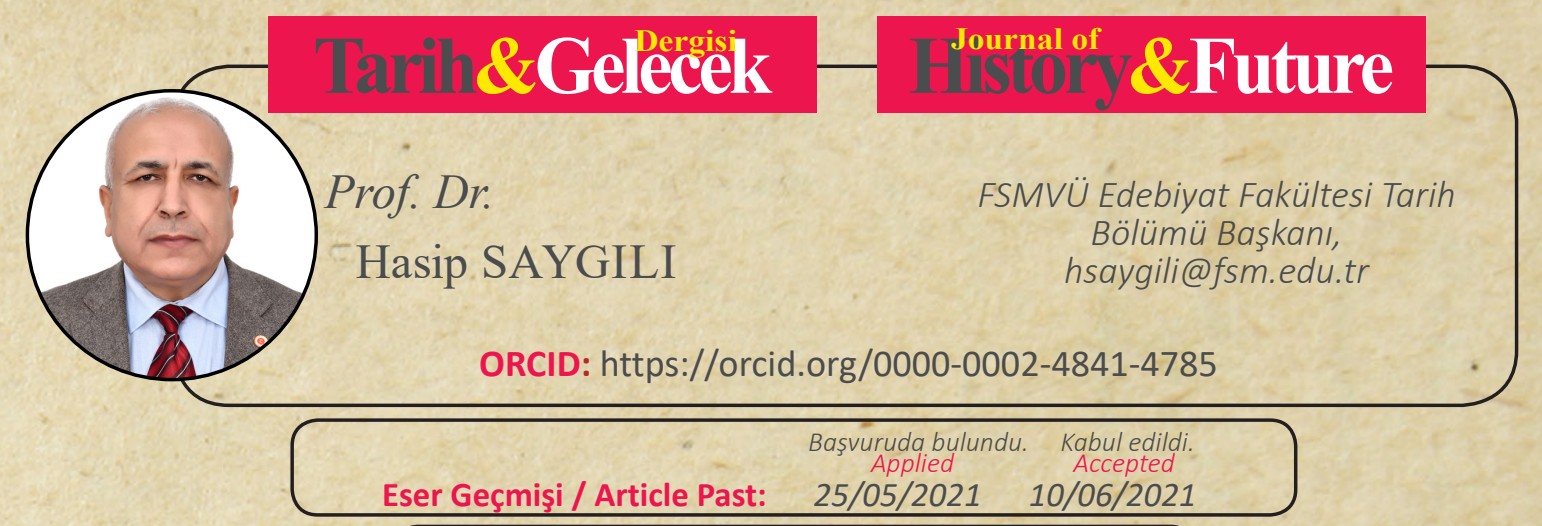

Araştırma Makalesi

DOI: http://dx.doi.org/10.21551/jhf.942718

Research Paper

Indexed by

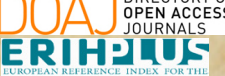

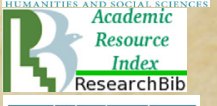

QISAM

Orjinal Makale / Orginal Paper

\title{
Gaziantep Savunmasının Hazırlık ve Teşkilatlanmasını Ali Cenani Bey mi Yaptı?
}

\section{Did Ali Cenani Bey Make Preperation and Organization of the Defense of Gaziantep?}

\section{Öz}

1919-1922 döneminde Mustafa Kemal Paşa’nın liderliği ile yürütülen Milli Mücadele’nin Güney cephesi askeri harekâtı ağırlıklı olarak gayrinizami kuvvetlerin yoğun şekilde kullanılmasıyla icra edilmiştir. Güneyde Antep savunması veya Antep Harbi diye bilinen harekât da kahramanlık ve fedakârlıklarla icra edilmiş ve başarıya ulaştırılmıştır. Gaziantep savunmasının tarihi ile ilgili birçok kaynakta bu harbin hazırlıklarının ve ilk teşkilatlanmasının daha Mondros mütarekesi imzalanmadan Ordu Komutanı Mustafa Kemal Paşa'nın verdiği talimatla Antep Mebusu Ali Cenani Bey tarafından başlatıldığı tekrar edilegelmiştir. Bu çerçevede Uluğ İğdemir, Yusuf Hikmet Bayur, Andrew Mango gibi itibarlı şahsiyetlerin de Ali Cenani merkezli iddiayı sorgulamadan eserlerinde aktardıkları görülmüştür. Bu iddianın kaynağı Falih Rıfkı Atay’ı 1926 yılında Hâkimiyet-i Milliye gazetesinde yazdıklarıdır. Bugüne kadar bu iddia itirazla karşılaşmadan popüler ve akademik yayınlarda varlığını sürdürmüştür.

Bu makalede bu yaygın iddia kaynak eleştirisi yapılarak, dönemin olguları ile beraber incelenmiştir. Sonuçta olgular ve yazılı birinci el kaynaklar üzerinden bu iddianın herhangi güvenilir bir dayanağı olmadığı gösterilmiştir. Ali Cenani anlatısının Türkiye’nin kurucu lideri Mustafa Kemal Atatürk'e hiç ihtiyaç yokken ileri görüşlülük atfetme işgüzarlığından kaynaklandığı sonucuna varılmıştır. Bu temelsiz iddianın gerçekliğe dayanmaması bir tarafa Türkiye karşıtı Ermeni çevrelerinde nasıl kullanıldığına da bu makalede işaret edilmiştir.

Anahtar Kelimeler: Milli Mücadele, Gaziantep (Ayıntap) Savunması, Antep Harbi, Ali Cenani, Falih Rıfkı 


\section{Abstract}

The military operations of the Southern front of the Turkish National Struggle, which was carried out under the leadership of Mustafa Kemal Pasha during the 1919-1922 period, was mainly executed by the intensive use of irregular forces. The operation known as the defense of Antep or the War of Antep in the South, was fulfilled with heroism and self sacrifice and achieved success. In many sources about the history of the defense of Gaziantep, it has been repeated that the preparations and the first organization of this war were initiated by the Antep Deputy Ali Cenani Bey, with the instructions given by the Army Commander Mustafa Kemal Pasha, even before the Mudros Armistice was signed. In this context, it has been observed that prestigious figures such as Uluğ İğdemir, Yusuf Hikmet Bayur and Andrew Mango also quoted the Ali Cenani-centered claim in their works without questioning it. The source of this claim is that Falih Rifkı Atay wrote in the newspaper Hâkimiyet-i Milliye in 1926. Until today, this claim has survived in popular and academic publications without any objection.

In this article, this common claim is examined together with the facts of the period by making a source criticism. As a result, it has been shown that this claim has no reliable basis, based on the facts and written primary sources. It was concluded that the narrative of Ali Cenani stems from his flattering to attribute farsightness to Turkey's founding leader Mustafa Kemal Atatürk, when there was no need for him yet. Apart from the fact that this baseless claim is not based on reality, it is also pointed out in this article how-it was used in anti-Turkey Armenian circles.

Keywords: Turkish National Struggle, Defense of Gaziantep (Aintab), War of Antep, Ali Cenani (Ali Djenani), Falih Rıfkı

\section{Giriş}

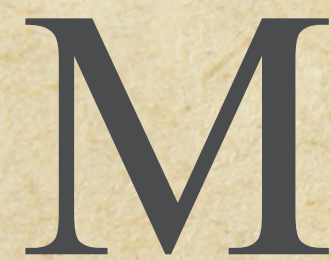

illi Mücadelede Antep savunmasının ağırlıklı olarak gayrinizami kuvvetlerle yürütüldüğ̈ ve daha Sivas Kongresi'nden itibaren Mustafa Kemal Paşa'nın emir ve talimatlarıyla yürütülüp başarıya ulaştığı bilinmektedir. Ancak bilinen bu olguya ve birçoğu yayınlanmış özgün belgeler koleksiyonuna rağmen Antep savunmasının temelinin daha Mondros mütarekesi imza edilmeden 7. Ordu/Yıldırım Orduları Grubu Komutanı Mustafa Kemal Paşa'nın talimatı ile başladığı ileri süren görebildiğimiz kadarıyla sorgulanmamış anlatılar da mevcuttur. Bu makalede bahsettiğimiz önemli iddianın gerçekliği araştırılmıştır. Bu iddianın arkasındaki saik tahmin edilmeye çalışılmıştır.

\section{İddianın Kaynağı Falih Rıfkı’nın 1926 Yılında Yazdıkları}

Bu yöndeki iddiaların anlaşıldığı kadarıyla kaynağı 1926 yılında Falih Rıfkı (Atay) Bey’in Hâkimiyet-i Milliye gazetesinde aktardığı Gazi Mustafa Kemal Paşa'nın anılarıdır. Bu anıları Atay 1955 yılında “Atatürk'ün Bana Anlattıkları" adıyla kitaplaştırmıştır. ' Burada konumuzla ilgili Antep savunması hazırlıklarının daha 30 Ekim 1918 Mondros mütarekesi imzalanmadan Atatürk'ün talimat ve girişimi ile başlatıldığı ileri sürülmektedir. Atay'a göre Gazi Mustafa Kemal Paşa kendisine Hâkimiyet-i Milliye' de yayınlanmak üzere hatıralarını anlattığı bir günde yanlarında bulunan o zaman Ticaret Bakanı olan Ali Cenani Bey söze karışmış “bir hatırasını" anlatmıştır. 
Buna göre 1918 Ekim ayının sonlarında Ali Cenani Bey Katma demiryolu istasyonunda karşılaştığı Mustafa Kemal Paşa' dan “milli mukavemet teşkilatı” için “Teşkilat yapın, milli bir kuvvet vücuda getirin, kendinizi müdafaa edin. Ben istediğiniz silahı veririm” talimatını almıştır. Falih Rıfkı'nın kanaatine göre "Filhakika o zaman Gazi Paşa'nın emri üzerine Antep'e verilen silahlar, meşhur müdafaa teşkilatının nüvesini teşkil etmiştir. "' Atay bu anlatısında Atatürk’ün Ali Cenani'nin ileri sürdüğü 8 yıl öncesine ilişkin "hatıraya" ne dediğini yazmamaktadır. Ancak bu anlatı gazetede yayınlanmıştır. Bu önemli iddiayı Falih Rıfkı Atay Çankaya adındaki meşhur eseri ve Atatürk’ten Hatıralar 1915-1919 kitabında da tekrarlamıştır.,

\section{Yasin Kutluğ'un İddiası}

Atay'ın ve ondan aktaranların iddialarını değerlendirmeden önce aynı yönde Gaziantep'ten de bir iddia gelmiştir. Bu iddianın kaynağı Birinci Dünya Harbi ve Milli Mücadele'de hizmetleri bilinen Mehmet Yasin Sani (Kutluğ) Bey'dir. Yasin Bey Birinci Meclis’te Ayıntap milletvekili olarak da görev yapmış ve yaşadığı dönem boyunca hizmetlerinden ötürü itibar görmüş bir kişilik olarak bilinmektedir. ${ }^{5}$ Bu kitabın yazarı da ortaokul öğrencisi iken rahmetlinin 1973 yılında Gaziantep'te düzenlenen cenaze törenindeki yoğun katılımı hatırlamaktadır. Kutluğ'un 1940 yılında Gaziantep'te İstihbarat Amiri olarak görev yaptığı sırada şehirde Halkevi yayın organı olan Başpınar dergisinde parça parça yayınlanan hatıralarının ilk bölümünde Yıldırım Ordular Grubu Komutanı Mustafa Kemal Paşa'nın Halep’ten çekilirken Orduya “Vilâyeti şarkiye efradını silahlar ile ve götürebilecekleri cephane ile terhis ediniz ” emrini verdiğini ileri sürülmektedir. ${ }^{6}$

\section{Mustafa Kemal Paşa Orduyu Emir Vererek Dağıtır mı?}

$\mathrm{Bu}$ iddia önemlidir. O günkü şartlar içerisinde böyle bir emir verilir mi sorusunun cevabı üzerinde durulmayı hak etmektedir. Bir komutan seviyesi ne olursa olsun Takım Komutanından Ordu Komutanına yapılan harekatın cinsi ne olursa olsun sevk ve idare ettiği birliğin bütünlügünü korumayı esas alır. Zaten askeri anlamda bozgun dediğimiz felaketler komutanların kendi birliklerini kontrol altında tutamamaları ve dağılmasıdır. Yoksa birliğin toptan imhası değildir. Komutan birliğine emir komuta edemez hale gelince işi bitmiş olur. Birliğin bütünlüğü ve harp kabiliyetini sürdürmek için emir komutayı muhafaza etmek personeli iaşe etmek kadar önceliklidir. Bu yüzden Medine müdafi Fahrettin Paşa'dan Filistin ve Suriye cephesindeki her seviyede komutan birlik bütünlüğünü korumak için çok ağır yaptırımlarla firarın önünü kesmeye çalışmışlardır. Başka türlüsünü de zaten düşünmek mümkün değildir.

$\mathrm{Bu}$ çerçevede bir Ordu Komutanının geri çekilme esnasında birliklerini düşmanın imhasına meydan vermeden güvenlikli bir bölgeye düzen ve intizam altında çekme yerine "herkes başını kurtarsın, silah ve cephaneyi de alın kaçın gidin" anlamına gelecek bir emir vermesi akla ve

2 Atay, Falih Rifk1, 72.

3 Atay, Falih Rıfkı, Çankaya (İstanbul: Bateş, 1980), 112-13; Atay, Falih Rıfkı, Atatürk'ten Hatıralar 1915 1919 (Ankara: Türkiye İş Bankası Kültür Yayınları, 1965), 73-74.

4 Atay, Falih Rıfkı, Çankaya; Atay, Falih Rıfk1, 112-13; Atay, Falih Rıfkı, Atatürk'ten Hatıralar 1915-1919, 73-74.

5 Şavkıl1, Cengiz, "Birinci Dönem TBMM'de Antep ve Maraş Milletvekilleri (Biyografileri ve Faaliyetleri)" (Yüksek Lisans, Kayseri, Erciyes Üniversitesi, 2000), 133-66.

6 Kutluğ, Yasin, "Millî Mücadeleye Tekaddüm Eden Günlerde Antepten Hatıralar”, Başsıınar, Temmuz $1940,11$. 
mantığa aykırıdır. Bir komutanın görevi kriz zamanlarında ne pahasına olursa olsun firarların önüne geçmektir. Firariler kurşuna dizilmek dâhil ağır yaptırımlara uğrarlar. Mesela Antep Harbi sürerken Sakarya Meydan Muharebesi (Ağustos-Eylül 1921) esnasında firarilerin kurşuna dizildiği tepenin adı İnfaz Tepe'dir. Bu yüzden üst seviye bir komutanın daha harp bitmemişken Şark vilayetlerinden neferlerin silahları ile serbest bırakılmasına ilişkin emir vermesi düşünülemez. Mütareke ordularımızın terhis edilmesini öngörmesine rağmen Harbiye Nezareti ve o günkü Genelkurmay Başkanlığının terhis işlemlerini mümkün olduğunca ağırdan almaya ve geciktirmeye çalıştığı bilinmektedir. Zaten Antep cephesinin de içinde bulunduğu Milli Mücadele liderliği, Sultan Reşat'ın 1914 yılında ilan ettiği Seferberliğin halen devam ettiği ${ }^{7}$ gerekçesini ileri sürmüş. $\mathrm{Bu}$ gerekçeye dayanarak terhisleri durdurarak asker kaçağı ve firarileri ile diğer askerlik mükellefi sayılanları gönüllü veya cebren askere alarak $^{8}$ ordu yeniden ayağa kaldırılmıştır. Bu sayede memleket düşman işgalinden kurtarılabilmiştir.

$\mathrm{Bu}$ gerçekler 1şığında Yasin Kutluğ’un iddiasını gerçeği yansıtmadığını söylemeliyiz. Muhtemelen Falih Rıfkı 1926 yılında yazdıklarından ilham alarak "Ebedi Şef” Mustafa Kemal Atatürk'ün ne kadar ileri görüşlü bir kişilik olduğunu vurgulamak için gayretkeşlikle bu çürük iddia ifade edilmiştir.

\section{Uluğ İğdemir Ne Diyor?}

Ancak bu tarz Antep savunmasının ilk girişiminin daha 1918 Ekimi'nde Dünya Savaşı sürerken Kurucu Lider Atatürk tarafindan silah ve cephane verilerek başlatıldığı iddiasını Falih Rıfkı Atay'dan sonra sadece yukarıda zikrettiğimiz Yasin Kutluğ ileri sürmüş değildir.

Uzun yıllar Türk Tarih Kurumu Genel Müdürlüğü yapmış birçok ciddiye alınır çalışmaya imza atmış Uluğ İğdemir de benzeri bir iddiayı ihtiyatlı bir dil ile ifade etmiştir: “Atatürk'ün Yıldırım Orduları Gurubu Komutanlığl'ndan ayrlarak Istanbul'a gitmeden önce de Adana'da terhis edilen askerlere, nasıl olsa düşman eline geçecek olan, at ve silahları dağıttı̆̆ söylentileri vardı." İğdemir bu iddianın kaynağı olarak herhangi bir referans vermemiştir. Düşmanın Çukurova'yı işgalinden yaklaşık iki ay önce silahların halka dağıtılması ihtimali pek makul değildir. Zaten Mustafa Kemal Paşa'nın Grup Komutanlığından ayrılıp Adana' dan ayrıldığı 7 Kasım 1918 tarihine kadar da pek terhis işlemi yapılmış değildir. İstanbul'da hükümetin İngilizlerin ağır baskısıyla vermek mecburiyetinde kaldığı terhis emirlerini komutanlar mümkün olabildiği kadar ağırdan alarak geciktirmeye çalışmışlardır. Bu çerçevede zaten terhisler 1919 baharına kadar da devam etmiştir. Ali Fuat Cebesoy anılarında Mustafa Kemal Paşa ile bu dönemde sürmekte olan "terhisleri derhal durdurmak" kanaatinde mutabık kaldıklarını yazmaktadır. Esasen Mustafa Kemal Paşa ile onun kolordu komutanlarından birisi sifatıla muhtemelen 5 veya 6 Kasım 1918 tarihinde Adana' da yaptığı görüşmede İngilizlerin Türk ordusunun süratle terhisi maksadını güttükleri ve bu maksadı gerçekleştirmek için emrivakiler yapmakta oldukları hususunda hemfikir olduklarını ifade

7 Keskin, Nuray Ertürk vd., ed., Açıklamalı Yönetim Zamandizini 1919-1928, c. 1, no: 6048 (Ankara: Ankara Üniversitesi Siyasal Bilgiler Fakültesi Kamu Yönetimi Araştırma ve Uygulama Merkezi, 2012), 240. 8 Haziran 1920'de 21 Temmuz 1914’te ilan edilmiş olan umumi seferberliğin fiilen devam ettiğine ilişkin 24 numaralı TBMM kararı.

8 Antep savunmasını incelediğimiz dönemde mesela Denizli Reddi İlhak Heyeti daha 18 Temmuz 1919 'da vatan müdafaasına iştirak etmeyen ihtiyat zabitlerinin idam edileceğini ilan etmiştir. Keskin, Nuray Ertürk vd., 1:107.

9 İğdemir, Uluğ, Atatürk'ün Yaşamı, 2. bs, c. I (Ankara: Türk Tarih Kurumu, 1988), 136. 
etmiştir. ${ }^{10}$ Bu yüzden düşman emeline hizmet edecek bozgundan arta kalan birliklerimizin süratle elden çıkarılması anlamına gelen terhisin daha ayrıntılı uygulama talimatı gelmeden erlere silah ve teçhizatın da verilerek gerçekleştirildiğini söyleyebilmek mümkün değildir.

\section{Kılıç Ali’den Andrew Mango’ya İddialar Sürüyor}

Yukarıda zikrettiğimiz ve kabulünü mümkün görmediğimiz Falih Rıfkı Atay merkezli iddiaların bir benzerini de Mehmet Ali Cenani Bey’e atfen Antep savunmasında emeği olan Kılıç Ali ${ }^{11}$ anılarında ileri sürmüştür. ${ }^{12},{ }^{13}$ Kılıç Ali, Yıldırım Orduları Grubu Komutanı Mustafa Kemal Paşa'nın Mondros mütarekesinden önce Halep kuzeyinde Ali Cenani'yi Katma'ya çağırarak Antep savunması için talimat verdiğini Cenani’ye atfen anlatmaktadır.

Nakledilen anlatıya göre önce Mustafa Kemal Paşa Halep önlerinde düşmanı durdurduğu zamanlarda zaten Ali Cenani de Adana'da kurulmuş olan Müdafaa-i Hukuk Cemiyeti'ne Antep temsilcisi olarak üye olarak katılmıştır. Katma'da Mustafa Kemal Paşa, Ali Cenani’ye yakında Türk beldelerinin kendilerini savunma zorunda kalabileceğinden bahisle ordunun elindeki silahları askerlik şubelerine verdireceğini söylemiş bu silahlara "sahip çıkın, hazırlıklarınızı bunlara dayandırın" demiştir. Bu çerçevede de ordu envanterinden Antep'e 4 bin mavzer, 26 makinalı tüfek ve 8 top verilmiştir. Daha önemlisi bu silahların depolanması için Ali Cenani Bey’e gizli emir de verilmiştir. Ayrıca yakında mütarekeyi kabul mecburiyeti olabilir, siz protesto ve mitinglere devam edin, demiştir. Atatürk'ün yakın çevresinden Kılıç Ali'nin ${ }^{14}$ beyanına göre Antep savunması daha Mondros mütarekesinden önce Ali Cenani delaletiyle Mustafa Kemal Paşa tarafından ordu demirbaşından verilen silahlarla yapılmıştır. Kılıç Ali’nin anlatısı benzeri içerikle Enver Behnan Şapolya tarafından Kemal Atatürk ve Milli Mücadele Tarihi adlı popüler kitapta da tekrar edilmiştir. Şapolya'ya göre Mustafa Kemal Paşa Cenani’ye “Teşkilat yapın, milli bir kuvvet vücuda getirin, kendinizi müdafaa edin. Ben istediğiniz silahı veririm.” O zaman Paşa'nın emri üzerine Antep'e verilen silahlar, meşhur müdafaa teşkilatının nüvesini teşkil etmiştir. ${ }^{15}$ Enver Behnan Şapolya'nın anlatısını neredeyse aynı kelimelerle Falih Rıfkı'nın yazdıklarıdır. ${ }^{16} \mathrm{Bu}$ iddialar kaynak gösterilmeden bir dönem Atatürk'ün Genel Sekreterliğini de yapmış olan Hikmet Bayur tarafından 1963 yılında yayınlanmış Atatürk'le ilgili kitabında da tekrarlanmıştır. Bayur'a göre Mustafa Kemal Katma'da Antep eşrafından Ali Cenani’ye rastlar ve ona teşkilat kurma ögüdü verir, silah verdireceği de söyler. "Gaziantep savunmalarının böylece temeli atılmıs olur."

10 Cebesoy, Ali Fuat, Milli Mücadele Hatıraları (İstanbul: Vatan Neşriyat1, 1953), 37, 29.

11 Güllü, Ramazan Erhan, "Kılıç Ali Bey ve Milli Mücadele'deki Faaliyetleri”, Çelebi, Aralık 2020.

12 Kılıç, Ali, Atatürk’ün Strdaşı Kılıç Ali’nin Anıları, ed. Hulûsi Turgut, 9. bs, Türkiye İş Bankası Kültür Yayınları 409 (İstanbul: Türkiye İş Bankası, 2007), 96-98.

13 Ali Kılıç - Erkinlik Savaşı Kağırmanlarından (Gaziantep: Gaziantep Halkevi, 1938).

14 Sabahattin Selek, Kılıç Ali’nin gördüğü itibarı izah ederken 1932 yılının ilk yarısında Atatürk'ün Başbakan İnönü ile 17 defa görüşürken, Kılıç Ali ile 49 defa görüştüğü ayrıca aynı kişiyi 7 defa evinde ziyaret ettiğini yazıyor. Selek, Sabahattin, Anadolu İhtilali, 5. bs (İstanbul: Örgün Yayınlar, 1981), 726.

15 Şapolyo, Enver Behnan, Kemal Atatürk ve Milli Mücadele Tarihi, 3. bs (İstanbul: Rafet Zaimler Yayınevi, 1958), 222,224.

16 Atay, Falih Rifki, Çankaya, 112-13.

17 Bayur, Hikmet, Atatürk Hayatı ve Eseri -I Doğumundan Samsun'a Çıkışına Kadar (Ankara: Atatürk Araştırma Merkezi, 1990), 188. 
Bayur'dan birkaç yıl sonra Falih Rıfkı'nın aktardığı anlatı Uluğ İğdemir tarafından da tekrarlanmıştır. ${ }^{18}$ Dahası Atatürk tarafından ciddi bir monografi kaleme alan Andrew Mango tarafından aynı iddialar Uluğ İğdemir kaynak gösterilerek bir daha tekrarlanmıștır. ${ }^{19}$

Mango önceki aktarımlardan farklı olarak şunları da kaydetmiştir: "Ne var ki Mustafa Kemal'in yerel Müslümanlara dağıttı̆̆ ya da iç kesimlere gönderdiği silahlar, daha doğuda Ali İhsan Paşanın aldığı benzer önlemler gibi, Itilaf devletlerinin Kilikya ile Yukarı Mezopotamya'yı işgal etmesini engelleyemedi. "20 Yani Mustafa Kemal Paşa'nın daha o zaman halka silah dağıtmasında bir kuşku yoktur. Ama bu silahlar daha sonraki işgallere mani olamamıştı.

Antep Harbi tarih yazımında çokça kullanılan yukarıda zikrettiğimiz kaynakların yanında Gaziantep şehir tarihçisi Cemil Cahit Güzelbey’e atfen Ali Cenani’nin oğlu Ekrem Cenani’nin notları arasında babasının yukarıdaki anlatıların kaynağındaki iddiaya benzer beyanlar bulunduğuna işaret etmek de gerekir. ${ }^{21}$

Bütün bu anlatılanlar - Bayur, İğdemir ve Mango gibi isimler tarafindan aktarılanlar dâhilkendi içinde tutarsızlıklar ile askerliğin temel mantığına aykırı iddialarla doludur. Dahası üzerinde tereddüt bulunmayan olgulara da uymayan iddialardır. Antep savunmasının nasıl teşkilatlandığını net olarak görebilmek için mitolojiye bulanmış anlatıların sorgulanması ve sağlam bir eleştiri süzgecinden geçirilmesi lüzumuna inandığımız için son aktarılan iddialarla ilgili de tespit ve görüşümüzü açıklayacağız.

\section{Olgular Neyi Anlatıyor?}

Mondros mütarekesi bilindiği gibi 30 Ekim 1918'de imzalanmıştır. Bir sonraki gün Mustafa Kemal Paşa Yıldırım Orduları Grubu Komutanlığına getirilmiştir. ${ }^{22}$ Mütareke'den önce iddia edildiği gibi bu makamda olması mümkün değildir. Kılıç Ali’nin işgale karşı 1918 Ekim sonlarında bölgede protesto ve mitinglere devam edilmesine dair talimat verilmesi iddiası kronolojik olarak doğru olamaz. Çünkü bu tarz eylemlerin 1919 Eylülünden itibaren Mustafa Kemal'in Heyet-i Temsiliye namına verdiği talimatlarla ortaya çıktığı bilinmektedir. ${ }^{23}$ Yine Kılıç Ali'nin Ali Cenani'nin Ekim 1918'de Adana Müdafaa-i Hukuk Cemiyetine Antep temsilcisi olarak üye olduğu iddiası da boşlukta kalmaktadır. Bu dönemde böyle bir teşkilat yoktur. Bu cemiyet daha iki ay kadar sonra 21 Aralık 1918 'de kurulacaktır. ${ }^{24}$

18 İğdemir, Uluğ, Atatürk'ün Yaşamı, I:135-36.

19 Mango, Andrew, Atatürk, çev. Doruker, Füsun (İstanbul: Sabah Kitapları, 2000), 191.

20 Mango, Andrew, 191.

21 “Oğlu Ekrem Cenani’nin notları arasında, babasının Birinci Dünya Savaşının bittiği günlerde İstanbul'dan Antep'e dönerken Kilis'in güneyinde Atatürk ile görüșerek elde ettiği 4.000 silahı Antep'e ve köylerine dağıttığını, Adana ve Maraş'ı da kapsayan Kilikya Müdafaa-i Hukuk Cemiyetini kuranlar arasında bulunduğu kaydedilmektedir": Şavkılı, Cengiz, "Birinci Dönem Türkiye Büyük Millet Meclisi’nde Antep Milletvekili Mehmet Ali Cenani Bey ve Faaliyetleri", Gaziantep University Journal of Social Sciences 7, sy 2 (01 Aralık 2008): 409.

22 Jaeschke, Gotthard, Türk Kurtuluş Savaşi Kronolojisi Mondros'tan Mudanya'ya Kadar (30 Ekim 1918 11 Ekim 1922) (Ankara: Türk Tarih Kurumu, 1970), 1.

23 Baykal, Bekir Sitkı, Heyet-i Temsiliye Kararları (Ankara: Türk Tarih Kurumu, 1974).

24 Kocaoğlu, Bünyamin, Mütarekede Ittthatçılık, Itttihat ve Terakki Fırkasının Dağılması (1918 -1920) (İstanbul: Temel Yayınları, 2006), 275. 
Askerlik açısından ise bir komutanın birlik demirbaşında bulunan silahların ileride size lazım olacak diye güvendiği birisine teslim etmesi düşünülebilecek bir konu değildir. Silah ve teçhizat teslimi resmi makamlar arasında olsa bile bu işlem tutanak ve senetle yapılır. Ağır bir mesuliyet ve yaptırım gerektirecek böylesi bir işlemin sadece şifahi bir emirle yerine getirilebileceğini varsaymak makul değildir. Esasen sözü edilen zamanlarda Ayıntap’ta Askerlik Şube Başkanı olarak Yarbay İrfan Bey adında dirayetli bir subay vardır. ${ }^{25}$ Usul, norm ve protokole özen gösteren Mustafa Kemal Paşa gibi bir şahsiyetin ordunun bilinen kural ve teamüllerini çiğneyerek askeri hiyerarşi içinde Yarbay İrfan Bey yerine, bahsi geçen devirde bütün felaketlerin müsebbibi olarak görülen İttihat Terakki'nin bölgedeki mutemedi Ali Cenani Bey vasıtasıyla geleceğe yönelik işleri yürütmesi akla ve mantığa uyacak bir şey değildir.

Diğer taraftan yaklaşık 40 gündür Filistin Nablus’ta bozgunu yaşayan Ordular Grubunun 7. Ordu Komutanı'nın adı Mustafa Kemal Paşa olsa bile ileride size lazım olabilir diye kendi sorumluluğunda bulunan önemli sayıda silahı resmibir sıfatı bulunmayan bir kişiye devredebileceğini kabul etmek akla yatkın görünmüyor.

Antep Askerlik Şubesi Başkanı İrfan Bey Antep savunması ile ilgili anılarını el yazısı ile kaleme alarak Harp Tarihi Arşivine teslim etmiştir. Askerlik Şube Başkanı bizzat içinde yaşadığı dönemde kendi kontrolündeki depolarda 400 civarında mavzer bulunduğu ve bunların Fransız işgal döneminde güvenlikli bir şekilde şehir dışına çıkarıldığını ifade etmektedir. Hali vakti yerinde olan herkesin bedelini ödeyerek güneydeki yerleşim merkezlerinden tüfek satın almaya teşvik edildiğini yazan İrfan Bey, Ali Cenani delaletiyle gizlice depolanan silahlardan söz etmemektedir. ${ }^{26}$

Bütün bu değerlendirmelerin yanında dönemle ilgili birinci el kaynaklarda arşiv belgeleri dâhil yukarıdaki Falih Rıfkı Atay merkezli iddialarını doğrulayacak bir bilgi hatta karineyle karşılaşıldığına dair bir emareye rast geldiğini bilebildiğimiz kadarıyla kimse ileri sürmüş değildir. Mesela Antep savunmasına dair daha 1924 yılında bizzat harbe subay olarak katılmış olan Mustafa Nurettin Bey'in kaleminden çıkmış meşhur kitabında Ali Cenani’nin Ermeni mahallesindeki evinden başka kendisine ve hizmetlerine bir atıf mevcut değildir. ${ }^{27}$ Literatürde Antep savunmasına dair birinci el kaynaklara dayanılarak yazılmış Sahir Uzel'in monografisinde de Cenani ismi görebildiğimiz kadarıyla geçmemektedir. ${ }^{28}$ Yine Antep savunmasına ihtiyat subayı olarak katılmış, Kilis yolu cephesinde Şahin Bey'in yardımcılığını yapmış olan dürüstlük ve hakşinaslığı ile bilinen Ali Nadi Ünler'in esaslı kitabında yukarıda zikrettiğimiz evi dışında Ali Cenani ile ilgili tek bir cümle görülmemektedir. ${ }^{29}$

Diğer taraftan İngiliz arşiv belgelerine göre Ali Cenani Malta'ya sürülmezden önce 8 Temmuz 1920'de İstanbul'da İngiliz Yüksek Komiserliğine verdiği dilekçede mütarekeden 20 gün önce Antep'e gitmek için ayrıldığını ve mütarekeden bir hafta sonra da İstanbul'a gitmek üzere

25 Efe, Aydın, “Antep Savunması: Bir Albayın Hatıratı”, A.Ü. Türkiyat Araşstırma Enstitüsü Dergisi, sy 53 (2015): 221-53.

26 Yakar, Halil İbrahim, Antep Savunması Hatıraları-Belgeler (Ankara: Gaziantep Büyükşehir Belediyesi, 2015), 344.

27 Mustafa Nurettin, Gaziantep Savunması, Kastaş 1912-1922 Türk Savaşları belgeseli (İstanbul: Kastaş A.Ş. Yayınları, 1989), 92-93.

28 Uzel, Sahir, Gaziantep Savaşının İç Yüzü (Ankara: Doğuş Ltd. O. Matbaası, 1952).

29 Ünler, Ali Nadi, Türkün Kurtuluş Savaşında Gaziantep Savunması (İstanbul: Kardeşler Matbaası, 1969), 62. 
Antep'ten ayrıldığını ifade etmektedir. ${ }^{30}$ Esasen Kasım 1918'den itibaren Antep'in geçirdiği işgal ve savunma dönemlerinde sancak ve mülhakatında Ali Cenani’yi gördügüüü söyleyen kimse de yoktur. Bu durumda 1918 Ekim ayının son günlerinden şehirden ayrılmasına kadar bir hafta ile 10 gün arası bir zaman zarfında Ali Cenani'nin halka silah dağıtması ve Antep savunması için teşkilatlanma yapması maddeten mümkün değildir. Zaten Ordu Komutanı Mustafa Kemal Paşa'nın resmi bir sıfatı bulunmayan bir kimseye ordu envanterindeki silahları devretmesinin kesinlikle mümkün olmadığını yukarıda değerlendirmiştik.

\section{Ermeni Anlatısına Göre Ali Ćenani}

Ama diğer taraftan Ermeni ve Ermeni taraftarı yayınlara gelince Ali Cenani'nin Antep Harbi'ndeki rolü en yüksek seviyededir. İncelediğimiz dönemle ilgili “1920'li yılların başında Antep'te Kemalist hareketin en nüfuzlu şahsiyetidir. 1922'de şehirde kalan son Ermenilerin de sürülmesinin arkasındaki en önemli figürdür"31 Türk karşıtı Ermeni tezlerini savunan bir yazar da önceki cümlede alıntıladığımız ifadeleri aynen tekrar etmekte, ayrıca Ali Cenani’nin mütarekeden sonra şehirde gizli milis gücü kurduğunu ileri sürmektedir ama İngilizlerle de irtibatını sürdürdüğünü ileri sürmektedir. Cenani’nin Müslüman halka silah dağıttığı da yazarın bir başka iddiasıdır. ${ }^{32} \mathrm{Bu}$ iddianın kaynağı Malta'da sürgün bulundurulan İttihatçı asker, mülki idareci ve aydınların uğradıkları hukuk dıșı muameleye dayanak olmak üzere hazırlanan "Türk Savaş Suçluları Dosyası"ndaki kanıtsız ve tutarsız beyanlardır. ${ }^{33}$ Mesela bu kapsamda dosyaya göre Ali Cenani Antep’ten göç ettirilen ve dörtte üçü öldürülen 25 bin Ermeni’nin mağduriyetinin baş sorumlularından birisidir.

Bu belgelerin tanzim edildiği dönemde Anadolu'da Milli Mücadele zemin tutmuş, hedefine adım adım ilerlemektedir. Milli Mücadele'nin ülke çapında teşkilatlanması ve elde ettiği başarı için İngilizler tarafından gerekçe aranırken Ali Cenani de İttihatçı bilindiğinden bölgede halka silah dağıttığı gibi iddialara yer verilmiş olmalıdır. ${ }^{34}$ Ama bu iddiaların herhangi bir kanıtı söz konusu değildir, dayanaksız spekülasyonlar olmaktan öte anlamı yoktur. Ali Cenani'nin Antep'te milis gücü kurduğuna ve halka silah dağıttığına dair dönemle ilgili kaynaklarda bir kayıt hatta ima görmediğimizi burada ifade etmeliyiz.

Ümit Kurt, Falih Rıfkı Atay kaynaklı malum iddiayı kaynak göstererek Ali Cenani’nin 19191921 döneminde Antep ve Adana'da Fransızlara karşı mukavemet hareketlerinin teşekkülünde merkezi rol oynadığını yazmaktadır. ${ }^{35}$ Fikrimizce Ermeni yanlısı literatür Ali Cenani’nin Ermeni tehcirinde şahsi çıkar elde ettiğine yönelik iddialarla onun Milli Mücadele'nin güney cephesindeki rolünü abartarak hatta bazen yoktan üreterek öne çıkarma eğilimindedir. İddianın ilk kısmının su

30 Yeghiayan, Varteks, Malta Belgeleri Ingiltere Dışişleri Bakanlığı "Türk Savaş Suçluları", çev. Değirmenciler, Julide (İstanbul: Belge Yayınları, 2007), 292.

31 Tashjian, Vahe, "The Expulsion of Non-Turkish Ethnic and Religious Groups from Turkey to Syria During the 1920s and Early 1930s", içinde Online Encyclopedia of Mass Violence (Paris: SciencePo., 2009), 5, http://www.massviolence.org/Article7id article $=330$.

32 Kurt, Ümit, "The Curious Case of Ali Cenani Bey: The Story of a Génocidaire During and After the 1915 Armenian Genocide", Patterns of Prejudice 52, sy 1 (01 Ocak 2018): 71, https://doi. org/10.1080/0031322X.2018.1430887.

33 Yeghiayan, Varteks, Malta Belgeleri İngiltere Dışişleri Bakanlı̆̆ı "Türk Savaş Suçluları".

34 Yeghiayan, Varteks, 292-99.

35 Kurt, Ümit, "The Curious Case of Ali Cenani Bey", 72. 
götürür yanı olabilir. Ama ikinci kısmı tamamen bir mitolojidir. Ancak Türkiye karşııı Ermeni propagandasının Türklerin işgalci güçlere karşı verdiği emsalsiz fedakarlıklarla dolu On Yıllık Harptekiölümkalım mücadelesini Ali Cenani’nin şahsındaçapulculuk, şahsinüfuzla servetkazanma, moral değerlerden yoksunluk gibi olumsuz niteliklerle resmetmek istediği ${ }^{36},{ }^{37},{ }^{38},{ }^{39}$ anlaşılabilir. Ermeni taraftarlarının Atay'ın iddiasını benimsemelerinin pratik pragmatik gerekçesinin burada saklı olduğu çıkarsanabilir.

\section{Ali Cenani Niçin Konuşmamış?}

Kendi şahsı etrafinda Antep savunmasının ilk teşkilatlanması ve hazırlıkları çerçevesinde kendisine Mustafa Kemal Paşa'nın talimat verdiği Falih Rıfkı tarafından 1926 yılında ileri sürülen Ali Cenani'nin bu iddiayı teyit ve tekrar etmemiştir. Önemli bir iddianın merkezindeki bu şahsın doğrudan konuşmamasını anlayabilmek için hayatındaki önemli kırılma noktalarına bakmak faydalı olacaktır.

Bilindiği gibi Ali Cenani önemli siyasi bir şahsiyettir. Zaten Osmanlı Meclis-i Mebusan'da 1. ve 2. Dönem Halep, 3. Dönem Ayıntap Milletvekili olarak bulunmuştur. Ayıntap'ta da İttihat Terakki'nin önde gelen bir siması olarak görülmektedir. Yukarıda zikrettiğimiz Ërmeni yanlısı literatür ve benzerleri de Ali Cenani'yi çok ağır ithamlarla Antep Ermenilerinin tehcir ve mağduriyetinin baş sorumlusu olarak gösterilmektedir. 1919 yılında da Heyet-i Temsiliye'nin desteği ile Antep’ten Meclis-i Mebusan'a milletvekili seçilmiştir. 1920 yılında diğer İttihatçılarla beraber Malta'ya sürülmüștür. ${ }^{40}$ Malta sürgünleri üzerine İngiliz belgelerini de kullanan duayen diplomat tarihçi Bilal N. Şimşir, Ali Cenani hakkında şu değerlendirmeyi yapmıştır:

"Ali Cenani Bey Ittihatçılar iktidardayken koyu İttihatçı kesilmişti. Talat Paşa'ya yanaşmıştı. Ama aslında yalnız iyi gün dostuydu. Itttihatçılığı, bölgesinden mebus seçilebilmek içindi. Seçilmişti. Antep yöresinde altı yedi köyün sahibiydi. Zengindi. Çokçasi İstanbul'da, Nişantaşı 'nda yaşardı. Kurtuluş Savaşının başında Kuvvayı Milliyeci gözüktü. Yine mebus seçildi. Müdafaa-i Hukuk Grubu mebusu olarak son Osmanlı Meclisine girdi. Ama Barış Antlaşmasılyla köylerinin Suriye'de kalacağını sezinledi. İşgalcilere, Hürriyet ve İtilafçılara kaydı. Ermeni sürgününden zengin olduğu söyleniyordu. Ingiliz arşivlerinde onun hakkinda oldukça lekeli bir dosya var.

İstanbul'un işgali üzerine Anadolu'ya geçmedi. İşgal kuvvetleriyle dostluk ilişskileri kurmaya çalış̧t. Nişantaşı'ndaki evinde Ermeni zenginlerine, Fransız, Italyan subaylarına davetler veriyordu. Amerikan Yüksek Komiserinin dostu olduğunu söylüyordu." ${ }^{41}$

36 Kurt, Ümit, "The Curious Case of Ali Cenani Bey"; Kieser, Hans-Lukas vd., ed., The End of the Ottomans - the Genocide of 1915 and the Politics of Turkish Nationalism (London, New York, vd: I.B. Tauris, 2019), 43, 269, 279-80, 291-93.

37 Kieser, Hans-Lukas, Talaat Pasha: Father of Modern Turkey, Architect of Genocide (Princeton, New Jersey: Princeton University Press, 2018), 383, 412.

38 Spier, Troy E. ve Poladian, Arpi, The Great Crime: An Aintab Diary, 2020, 109-10, 110, 112, 126, 135-36, 147.

39 Gesar, A, Antep’in Varoluş Mücadelesi, çev. Kurt, Ümit ve Uçaner, Murad (İstanbul: Belge Yayınları, 2015), 8-9.

40 Şavkılı, Cengiz, "Birinci Dönem Türkiye Büyük Millet Meclisi’nde Antep Milletvekili Mehmet Ali Cenani Bey ve Faaliyetleri".

41 Şimşir, Bilal N., Malta Sürgünleri, 2. bs (İstanbul: Bilgi Yayınlar, 1985), 317-18. 
Bilal Şimşir'in anlattıklarını İngiliz arşiv kaynakları da doğrulamaktadır. Buna göre Ali Cenani Nişantaşı'nda son derece görkemli bir şekilde yaşamaktadır. Eşi ve kızı 1919 yılı boyunca "sık sık Amerikan, Fransız ve Italyan subaylarıyla sivillerini çay partilerinde, yemek davetlerinde eğlendirmekteydiler. "'42, 43

Duayen diplomat tarihçi Bilal Şimşir, Ali Cenani’nin işgal güçlerine sergilediği bu davranışlarına rağmen İstanbul'un işgalinden dört ay sonra İngilizler tarafından tutuklandığını yazmaktadır. Arapyan Hanı'nda İngiliz Yüksek Komiserliğine 7 Temmuz 1920 tarihinde bir dilekçe verdiğini ifade etmektedir. Bu dilekçede Ali Cenani şunları beyan etmiştir: "Ben hiçbir zaman Talat ve Enver Paşalarının dostu olmadım... Beni milliyetçi diye suçluyorlar... Onların savaşına katılmaya asla niyetim yok. Antep'in geleceği Müttefiklerce saptanıncaya kadar tarafsız kalmayı yeğ tutuyorum. Parlamentoda milliyetçilere katılmadım. Onlara açıkça karşı çıktım. Parlamento üyelerinin çoğu Anadolu 'ya geçti ve Kemal Paşa ya katıldı. Ben İstanbul'da kaldım. Kemalistler benim köylerimi yağma ettiler. Milliyetçilerin saldırılarından korkan yakınlarımın çoğu Halep'e kaçtılar." 44

Şimşir'in değerlendirmesine göre Ali Cenani’nin “tutarsız sözleri, dönekliği, çıkarcılı̆̆ İngilizlerce de not edilmişti." Ancak "Kemalistleri Ingilizlere jurnal etmekten çekinmeyen Ali Cenani Bey, Malta'dan bir Kemalist kahraman gibi döndü. TBMM'ne girdi. Cumhuriyetin ilk yıllarında bir süre Ticaret Bakanı da oldu... "45

Ali Cenani’nin Falih Rıfkı tarafından yaratılan ve neredeyse literatüre yerleşen Milli Mücadele'de Antep cephesinde ilk planlama ve teşkilatlanmayı daha 1918 yılında Atatürk'ün talimatıyla yaptığı algısını kendisinin niçin doğrudan bir anlatıyla tekrar etmediği sorusunun muhtemel cevabı 1924-1926 yıllarında yapmış olduğu Ticaret Bakanlığı sırasında adının makamı ile ilgili akçalı işlere karışması ile suçlanıp yargılanarak "vazifeyi suiistimalden” hapse mahkum edilmesi ${ }^{46}, 47,{ }^{48}$ olmuş olabilir.

Ancak bu mahkumiyete rağmen Ali Cenani, "uygunsuz işlere son vermemiş" ve neredeyse öldüğü zamana kadar akçalı işlerde dürüstlükle bağdaşmayan kötü bir profil çizmişs ${ }^{49}$ ve bu durum kamuoyuna yansımıştır. ${ }^{50}$ Bütün bu gelişmeler de Cenani'nin Falih Rıfkı'nın efsanenin başlangıcı olan 1926'daki iddiasını tekrarlayıp kendi adına Atatürk'ü referans göstererek Antep Harbi'nde

42 Yeghiayan, Varteks, Malta Belgeleri İngiltere Dışişleri Bakanlığı "Türk Savaş Suçluları", 295.

43 Ermeni Patriği Zaven hatıralarında işgal yıllarında bazı Türklerin İstanbul'da müttefik ülke temsilcileriyle onur kırıcı ilişkiler kurduğunu ileri sürmektedir: Georgelin, Herve, "La Renaissance and the Aftermath of World War I", içinde Armenian Constantinople, UCLA Armenian History and Culture Series (California: Mazda Publishers, 2010), 426.

44 Şimşir, Bilal N., Malta Sürgünleri, 318.

45 Şimşir, Bilal N., 318.

46 Çoker, Fahri, Türk Parlamento Tarihi Millî Mücadele ve TBMM I. Dönem 1919 - 1923, 3. Cilt (Ankara: Türkiye Büyük Millet Meclisi Vakfı Yayınları, 1995), 427.

47 Afşar, Erkan, "Yolsuzluk ve Usulsüzlük Olaylarının Türk Siyasetine Yansımaları (1923-1950)" (Erzurum, Atatürk Üniversitesi, 2013).

48 Kocaman, M. Aydın, "Basinda Ali Cenani Bey ve Mahmut Muhtar Paşa" (İzmir, 9 Eylül Üniversitesi, 2006), 13-48.

49 Yazar, Cumhuriyet gazetesinde Ali Cenani ile ilgili yayınlanan olumsuz haberleri de zikretmiştir: Kurt, Ümit, "The Curious Case of Ali Cenani Bey", 73-74.

50 Yapılan bir doktora çalışmasında Ali Cenani'nin mahkumiyetinden sonraki dönemde hakkında çıkan olumlu bir haber olmadığı dönemin gazeteleri Hatimiyet-i Milliye, Vakit ve Akşam gazetelerindeki haberler değerlendirilerek verilmiştir: Akan. Hatice, "Mehmet Ali Cenani Bey’in Hayatı ve Parlamento Faaliyetleri (1872-1934)" (Sakarya, Sakarya Üniversitesi, 2018), 188-93. 
aslan payının kendisine ait olduğu anlamına gelecek iddiayı tekrarlayacak ortamı bulamamış olmasının diğer sebebi sayılabilir.

\section{Sonuç}

Adlarını andığımız Yasin Kutluğ ve Kılıç Ali’nin Antep savunmasına hizmetlerinin geçmesi yukarıda dayanaksız olduğunu gösterdiğimiz iddiaların günümüzün yaygın deyimiyle şehir efsanesi haline gelmesine katkı sağlamış olmalıdır. Bu tarz gerçeküstü anlatıların literatürde sorgulanmamasının başat sebebi de bütün anlatıların Türkiye Cumhuriyeti'nin dirayetli kurucu lideri Mustafa Kemal Atatürk’e hiçbir ihtiyaç yokken öngörülerinin ne kadar isabetli olduğunu gösterme gayretkeşliğinden olsa gerektir. Diğer taraftan Kılıç Ali ile Falih Rıfkı Atay’ın Atatürk'ün çok yakın çevresinden kimseler olmaları da aktardıkları anlatıların yarattığı gerçek dışı algıya bir nevi dokunulmazlık sağlamış da denebilir. Basitçe Mustafa Kemal Paşa anlatının içinde mevcutsa gerçekliğinden kuşkuya gerek kalmaz tarzında yaygın kabulün efsanenin inşasını ve yaşamasını sağladığını kabul etmek yanlış olmayacaktır.

Tarih metodolojisine özen gösterme lüzumu duymayan popüler ve hatta bazı akademik yazımda Antep Harbi veya Milli Mücadelenin başlangıcı anlatılarında bu tarz bağlama ve kaynağa dayanmayan hatırat kaynaklı iddiaların sorgulanmadan gerçek olarak kabul edilmesi fikrimizce isabetli değildir. Diğer taraftan Türkiye karşıtı Ermeni çevrelerin Ali Cenani’ye hak etmediği itibarı kendi tezlerine dayanak olarak kullanmakta olduklarına da işaret edilmesi gerekir.

\section{Kaynaklar}

Afşar, Erkan. "Yolsuzluk ve Usulsüzlük Olaylarının Türk Siyasetine Yansımaları (19231950)”. Atatürk Üniversitesi, 2013.

Akan. Hatice. "Mehmet Ali Cenani Bey’in Hayatı ve Parlamento Faaliyetleri (1872-1934)". Sakarya Üniversitesi, 2018.

Ali Kılıç - Erkinlik Savaşı Kağırmanlarından. Gaziantep: Gaziantep Halkevi,-1938.

Atay, Falih Rıfkı. Atatürk’ten Hatıralar 1915-1919. Ankara: Türkiye İş Bankası Kültür Yayınları, 1965.

—. Atatürk'ün Bana Anlattıkları. İstanbul: Cumhuriyet gazetesi, 1998.

C Çankaya. İstanbul: Bateş, 1980.

Baykal, Bekir Sitkı. Heyet-i Temsiliye Kararları. Ankara: Türk Tarih Kurumu, 1974.

Bayur, Hikmet. Atatürk Hayatı ve Eseri -I Doğumundan Samsun'a Çıkışına Kadar. Ankara: Atatürk Araştırma Merkezi, 1990.

Cebesoy, Ali Fuat. Milli Mücadele Hatıraları. İstanbul: Vatan Neşriyatı, 1953.

Çoker, Fahri. Türk Parlamento Tarihi Millî Mücadele ve TBMM I. Dönem 1919 - 1923, 3. Cilt. Ankara: Türkiye Büyük Millet Meclisi Vakfı Yayınları, 1995.

Efe, Aydın. “Antep Savunması: Bir Albayın Hatıratı”. A.Ü. Türkiyat Araştırma Enstitüsü Dergisi, sy 53 (2015): 221-53.

Georgelin, Herve. "La Renaissance and the Aftermath of World War I". İçinde Armenian Constantinople, 401-29. UCLA Armenian History and Culture Series. California: Mazda Publishers, 
2010.

Gesar, A. Antep'in Varoluş Mücadelesi. Çeviren Kurt, Ümit ve Uçaner, Murad. İstanbul: Belge Yayınları, 2015. 2020.

Güllü, Ramazan Erhan. “Kılıç Ali Bey ve Milli Mücadele’deki Faaliyetleri”. Çelebi, Aralık

İğdemir, Uluğ. Atatürk'ün Yaşamı. 2. bs. C. I. Ankara: Türk Tarih Kurumu, 1988.

Jaeschke, Gotthard. Türk Kurtuluş Savaşi Kronolojisi Mondros'tan Mudanya'ya Kadar (30 Ekim 1918 - 11 Ekim 1922). Ankara: Türk Tarih Kurumu, 1970.

Keskin, Nuray Ertürk, Çelik, Fatma Eda, Aydın, Recep, Bayrak, M. Burcu, Yılmaz, Aslı, ve Dik, Esra, ed. Açıklamalı Yönetim Zamandizini 1919-1928. C. 1. no: 604 8. Ankara: Ankara Üniversitesi Siyasal Bilgiler Fakültesi Kamu Yönetimi Araştırma ve Uygulama Merkezi, 2012.

Kılıç, Ali. Atatürk’ün Sırdaşı Kılıç Ali’nin Anıları. Editör Hulûsi Turgut. 9. bs. Türkiye İş Bankası Kültür Yayınları 409. İstanbul: Türkiye İş Bankası, 2007.

Kieser, Hans-Lukas. Talaat Pasha: Father of Modern Turkey, Architect of Genocide. Princeton, New Jersey: Princeton University Press, 2018.

Kieser, Hans-Lukas, Anderson, Margaret Lavinia, Bayraktar, Seyhan, ve Schmutz, Thomas, ed. The End of the Ottomans - the Genocide of 1915 and the Politics of Turkish Nationalism. London, New York, vd: I.B. Tauris, 2019.

Kocaman, M. Aydın. "Basinda Ali Cenani Bey ve Mahmut Muhtar Paşa”. 9 Eylül Üniversitesi, 2006.

Kocaoğlu, Bünyamin. Mütarekede Ittihatçılık, Ittihat ve Terakki Fırkasının Dağılması (1918 -1920). İstanbul: Temel Yayınları, 2006.

Kurt, Ümit. "The Curious Case of Ali Cenani Bey: The Story of a Génocidaire During and After the 1915 Armenian Genocide”. Patterns of Prejudice 52, sy 1 (01 Ocak 2018): 58-77. https:// doi.org/10.1080/0031322X.2018.1430887.

Kutluğ, Yasin. "Millî Mücadeleye Tekaddüm Eden Günlerde Antepten Hatıralar”. Başpınar, Temmuz 1940.

Mango, Andrew. Atatürk. Çeviren Doruker, Füsun. İstanbul: Sabah Kitapları, 2000.

Mustafa Nurettin. Gaziantep Savunması. Kastaş 1912-1922 Türk Savaşları belgeseli. İstanbul: Kastaş A.Ş. Yayınları, 1989.

Selek, Sabahattin. Anadolu Ihtilali. 5. bs. İstanbul: Örgün Yayınlar, 1981.

Spier, Troy E. ve Poladian, Arpi. The Great Crime: An Aintab Diary, 2020.

Şapolyo, Enver Behnan. Kemal Atatürk ve Milli Mücadele Tarihi. 3. bs. İstanbul: Rafet Zaimler Yayınevi, 1958.

Şavkılı, Cengiz. "Birinci Dönem TBMM'de Antep ve Maraş Milletvekilleri (Biyografileri ve Faaliyetleri)". Yüksek Lisans, Erciyes Üniversitesi, 2000.

—_. "Birinci Dönem Türkiye Büyük Millet Meclisi’nde Antep Milletvekili Mehmet Ali 
Cenani Bey ve Faaliyetleri”. Gaziantep University Journal of Social Sciences 7, sy 2 (01 Aralık 2008): 405-25.

Şimşir, Bilal N. Mälta Sürgünleri. 2. bs. İstanbul: Bilgi Yayınlar, 1985.

Tashjian, Vahe. "The Expulsion of Non-Turkish Ethnic and Religious Groups from Turkey to Syria During the 1920s and Early 1930s". İçinde Online Encyclopedia of Mass Violence. Paris: SciencePo., 2009. http://www.massviolence.org/Article7id article=330.

Uzel, Sahir. Gaziantep Savaşının İç Yüzü. Ankara: Doğuş Ltd. O. Matbaası, 1952.

Ünler, Ali Nadi. Türkün Kurtuluş Savaşında Gaziantep Savunması. İstanbul: Kardeşler Matbaası, 1969.

Yakar, Halil İbrahim. Antep Savunması Hatıraları-Belgeler. Ankara: Gaziantep Büyükşehir Belediyesi, 2015.

Yeghiayan, Varteks. Malta Belgeleri Ingiltere Dışişleri Bakanlığl "Türk Savaş Suçluları". Çeviren Değirmenciler, Julide. İstanbul: Belge Yayınları, 2007. 